\title{
THE NEW ALBERTA PLANNING ACT
}

\author{
P. S. ELDER*
}

The 1977 Planning Act is assessed and compared with the development process under the former Act. The author advocates increased public participation and greater attention to environmental concerns under the new Act.

\section{INTRODUCTION}

On April 1, 1978 The Planning Act, $1977^{1}$ of Alberta came into force. ${ }^{2}$ Its enactment was preceded by about five years' study and public debate, and the authors of the original public working paper were told that "the new Planning Act was to be the best in North America". ${ }^{3}$

This article does not compare the new Act with those in other jurisdictions, but assesses the adequacy of its planning framework for a booming growth area in an increasingly expensive and resource scarce world. Although this is largely a legal analysis, the intimate relationship of planning and law results in general remarks about planning and land use approval, concepts and techniques. As well, numerous textual ambiguities and interpretive problems are exposed, and suggestions made for improvement. Careful study of the Act's provisions, however, reveals some of the earlier public criticism to be unfounded.

In some areas the new Act is a significant improvement over its predecessor, although it must also be conceded that (apart from some dreadful drafting) the old Act' offered more flexibility to municipalities than they used. The new Act gives reasonable scope for good land use planning, if municipalities will take advantage of it. Where both Acts (and much other provincial legislation) have fallen down seriously, it seems to $m e$, is in their failure to provide direction, to encourage or even require innovation in a variety of serious urban problems. Alberta has soaring house and land prices, a growing population and dynamic economy. A variety of other urban and environmental issues present themselves. Without claiming that all of these can easily be dealt with, much more could be done.

After a brief summary of the new Act, the former development control process will be described, with the conclusion that either its pure form or the timid Alberta version could still be used. Various innovative zoning techniques are also now available (and most probably were under the former Act as well).

The new Act will be assessed generally, and some topics will be discussed in depth. Development agreements, it is submitted, are somewhat more limited than formerly. The Act is not as overly centralist as many critics have claimed, nor does it appear to force serious increases in length of the

- Professor of Law, Faculty of Environmental Design, The University of Calgary. I would like to thank the following person for their criticism of the draft article: Brand Inlow, Assistant City Solicitor, City of Calgary, and Professors Don Detomasi and Walter Jamieson, Faculty of Environmental Design, The University of Calgary.

1. S.A. 1977 , c. 89 . Unless otherwise indicated, all sections referred to are from this act.

2. Alberta Gazette, Part 1, Vol. 74, No. 6 (Mar. 31, 1978).

3. "Towards a New Planning Act For Alberta", Alberta Department of Municipal Affairs (1973)

4. R.S.A. 1970, c. 276, as am. (hereafter cited as "old Act"). 
approval process (although it unnecessarily does so in some cases). The provisions regarding public participation and the environment could be much improved, although on the latter topic, other legislation must also be considered.

Overall, my conclusion is that if the new Act is "the best in North America", the competition is not very stiff. It is adequate, even good in some ways. But it is not superb, and for five years' work it should have been.

\section{THE ALBERTA PLANNING ACT, 1977}

\section{The Alberta Planning Act's purpose. ${ }^{5}$}

$\ldots$ is to provide means whereby plans and related measures may be prepared and adopted to

a) achieve the orderly, economical and beneficial development and use of land and patterns of human settlement, and

b) maintain and improve the quality of the physical environment within which patterns of human settlement are situated in Alberta

without infringing on the rights of individuals except to the extent that is necessary for the greater public interest.

To do this, a hierarchy of planning authorities and of plans are envisaged. As well, subdivision and development approval processes are to be established, generally within the control of municipal governments, and an appeal process is provided.

\section{A. The Planning Process}

The planning process may be sketched first. Regional Planning Commissions (R.P.C.s, of which eight presently exist) ${ }^{6}$ are to prepare and adopt a Regional Plan by December 31, 1982. "This is "the broadest plan possible in the Province of Alberta"s and it

a) shall provide for the present and future land use and development of the planning region, and

b) may regulate and control the use and development of land in the planning region. ${ }^{\theta}$

These commissions are made up of members chosen by those municipal councils (in the region) designated by the Minister. Both municipalities and members of the public must be given a chance to react to the draft plan.

Once an R.P.C. adopts a regional plan, it is sent to the Alberta Planning Board, whose members are appointed by Order in Council. The Board reviews the plan, and may return it to the R.P.C. for suggested changes. After the review, the Board forwards the plans, with recommendations, to the Minister of Municipal Affairs (hereafter "the Minister") upon whose ratification the plan comes into effect. After this, no local authority can take or authorize any action or development which is inconsistent with it ${ }^{10}$. Furthermore,every subordinate plan, land use by-law and decision of a development approval agency or officer ${ }^{11}$ must conform with the Regional Plan.

5. S. 3.

6. Alta. Regs. 133-139/78.

7. S. 46 .

8. Speech of Honourable Dick Johnston, Minister of Municipal Affairs, Legislative Assembly of Alberta, Alberta Hansard, Number 64, Friday, October 21, 1977.

9. S. 46.

10. S. 53(1).

11. S. 53. Both under the old and new Acts, approving authority may be delegated to a Development Officer or Municipal Planning Commission. For ease of reference, however, the text will usually refer only to the Development Officer. 
The middle level plan is the General Municipal Plan, which must be prepared and adopted by most municipalities, counties or municipal districts. ${ }^{12}$ This plan must describe proposed land uses, the sequence and manner proposed for future development, and must also designate the areas suitable for the third level of plan. ${ }^{13}$ No provincial approval is required.

Presumably the Municipal Planning Commission would be involved in this process, although this is not spelled out.

A third level of plan, Area Structure Plans and Area Redevelopment Plans, must conform to the General Municipal Plan, ${ }^{14}$ and the Redevelopment Plan, but not the Structure Plan, must also conform to the land use bylaw. Apparently, the land use by-law need not conform to any plan but the Regional Plan, a most interesting omission. Thus, theoretically, land uses could be in accord with the General Municipal Plan, yet be non-conforming uses because of the land by-law.

An Area Structure Plan can be used only when "subsequent subdivision and development ${ }^{\text {(15 }}$ are contemplated, that is, for previously undeveloped areas. The Structure Plan must include proposals for the sequence of development for land uses, population density and general location of major transportation routes and public utilities. ${ }^{16}$

The Act declares a sufficient range of purposes for the Redevelopment Area that it is adaptable for both "established" and decaying neighbourhoods. It may be declared for the purposes of preserving or improving land and buildings; rehabilitating or removing buildings; establishing, improving or relocating roadways or utilities; or any other development. ${ }^{17}$

The required contents of the Redevelopment Plan imply that somewhat greater detail is expected in this plan. As in the Structure Plan, the proposed land uses must be specified, but instead of "general location of major transportation routes and public utilities," 18 the Redevelopment Plan requires description of "the proposed public roadways, public utilities and other services." ${ }^{19}$ The location of reserve land, recreational and educational facilities likely to be required must be described ${ }^{20}$ but this is not required in the Structure Plan, presumably because municipal and school reserves are calculated and located during the subsequent subdivision phase. ${ }^{21}$

12. S. 59(1).

13. S. 61 .

14. Ss. $62(2)(a)$ and $65(a)$.

15. S. 62(1).

16. S. 62(2).

17. S. 63(a).

18. S. 62(2)(b)(iv).

19. S. 65(b)(iii).

20. S. 65(b)(iv) and (v).

21. It is interesting that Calgary used three levels of plan in approving new housing subdivisions, apart from the Regional and General Municipal Plans. These were the Design Brief (about four square miles), the Outline Plan [one quarter to one half section (160 - 320 acres)] and the Tentative Plan (20-30 acres). City officials have expressed concern that they will lose the latter two plans since they are not mentioned in the new Act, but there seems little reason for concern. After all, none of these three had any legislative sanction under the former Act, or Development Control By-law. It seems their existence rested on the discretion of the subdivision approving authority, which can require the necessary information in order to decide on an application. 


\section{B. The Development Approval Process}

These are the plans - what about implementation? Considering that the dynamic growth of the province's two biggest cities results in the creation of large new housing subdivisions every year, it is appropriate to consider the subdivision approval process first.

\section{1) Subdivisions}

Formerly, the subdivision approving authority was the Municipal Planning Commission of Calgary and Edmonton, or otherwise the Regional Planning Commission (or the Provincial Planning Director for areas outside the Regional Planning Areas). The new Act continues the authority of the M.P.C. in Calgary and Edmonton, subject to decision of City Council ${ }^{22}$ and permits the Minister to authorize other municipal councils to approve subdivision themselves. In turn, these councils may delegate this power to their Municipal Planning Commission and may consent to further subdelegation to one or more M.P.C. members; failing this authorization by the Minister, the Regional Planning Commission (or its delegate), or the Minister (or his delegate) for municipalities outside the planning regions, has the responsibility for approving subdivisions. ${ }^{23}$

The approving authority may approve an application only if, inter alia, the land is suitable for its intended purpose, and if the proposed subdivision conforms to any plans and land use by-laws covering the area, and to the Planning Act and regulations. ${ }^{24}$ If these requirements are met, the approving authority may approve, refuse, or impose conditions including the execution of a development agreement respecting the construction of, or paying for, various services or utilities. ${ }^{25}$

Provision is also made for the deduction, without compensation, of land for public roadways and utilities, environmental reserves, reserves for municipal and/or school purposes or for the levy of monies in lieu of the latter. ${ }^{28}$

Appeals on subdivision decisions may be made to the Alberta Planning Board. ${ }^{27}$

\section{2) Development}

Under the new Act, the land use by-law is the main tool of the development approval process after the subdivision stage. The Act fails, however, to stipulate the relationship of the by-law to the Municipal Plan, although both must conform with the Regional Plan. ${ }^{28}$ The land use by-law must be passed by municipalities of 1,000 or more people ${ }^{2 \theta}$ and it "may prohibit or regulate and control the use and development of land and buildings within a municipality" ${ }^{30}$ Predictably, the by-law must divide the municipality "into

22. S. 159.

23. Ss. 85 and 32 .

24. S. 88(1).

25. S. 89.

26. S. 92.

27. S. 103.

28. S. 53(2).

29. S. 66(1).

30. S. $67(1)$. 
districts of such number and area as the council considers appropriate". ${ }^{31}$ Unless the district is designated as a "direct control district", the by-law must prescribe for each district, "with or without conditions", the permitted and/or discretionary uses of land or buildings. ${ }^{32}$

The land use by-law may (but need not) contain a long list of provisions on size of lots, height and bulk controls, landscaping, population densities, design characteristics and other features common to traditional zoning bylaws. ${ }^{33}$

The Act clearly envisages that, with minor exemptions which the land use by-law may stipulate, any development without a development permit is to be illegal. ${ }^{34}$ The by-law must provide procedures for the Development Officer to decide on applications for development permits, including the extent of his discretion or power to affix conditions. ${ }^{35}$ Procedures must also be implemented to inform owners of lands likely to be affected where the development involves a discretionary decision. ${ }^{36}$ Decisions of the Development Officer may be appealed to the Development Appeal Board (D.A.B.), either by the applicant or by someone affected by the order, decision or development permit. ${ }^{37}$ Unless discretion is given by the land use by-law, the Development Officer must issue a permit in respect of a permitted use which conforms to the other requirements of the land use by-law. ${ }^{38}$ The D.A.B. is bound by all plans and by the land use by-law ${ }^{39}$ (which, apparently, need not comply with the plans). It can, however, permit developments which do not comply with the land use by-law if neighbourhood amenities, or the use or value of neighbouring properties, are not substantially interfered with, and if the proposed development does not conflict with uses prescribed in the by-law. ${ }^{10}$ A similar power may be given to the Development Officer by a land use bylaw. ${ }^{41}$

Conventional provisions are made for nonconforming uses ${ }^{42}$ and the Development Officer has strong enforcement powers." ${ }^{4}$

A municipal council has power to require a development agreement, as a condition of issuing a permit, apparently whether or not the use is permitted or discretionary within the relevant district." The terms which can be imposed are identical to those which can be exacted under section 89 as a condition of subdivision approval (these differed under the former Act, as will be explained below).

31. S. 67(2)(a).

32. S. $67(2)(b)$.

33. S. 67(3).

34. S. 81.

35. S. 67(c)(d).

36. S. 67(e).

37. S. 81(3) and 82(1).

38. S. 69(2).

39. S. 83(3)(a)

40. S. $83(3)(c)$.

41. S. 67(5).

42. S. 72.

43. S. 79(1).

44. S. 75. 


\section{Other Provisions}

The Act also provides for such procedures as use and disposal of reserve land, cancellation of plans of subdivision, replots, and appeals to the Appellate Division of the Supreme Court of Alberta on a question of law or jurisdiction from a decision of the Alberta Planning Board or Development Appeal Board. Several other interesting features deserve mention.

First, there are provisions ${ }^{45}$ for a Ministerial order (only upon application of a council) designating an area within the municipality an Innovative Residential Development Area. After this order

... council may, notwithstanding any provision of this Act or the regulations, approve a project for innovative kinds of lower cost residential development whether or not the project is in conformity with any land use by-law.

It would, of course, be ultra vires for council to approve "noninnovative kinds" of lower cost residential development. One wonders what the courts would consider an innovation.

The Minister may approve plans of subdivision within an Innovative Residential Development Area, in spite of the Act and Regulations. ${ }^{46}$ Within the area, he may waive anything in the Act, Regulations or land use by-law, and may take any other action or procedure which he considers desirable in the public interest. Naturally, this power will have to be limited to the purposes of the Planning Act."

The second provision of interest is the power of the Lieutenant Governor in Council to establish by regulation "any area of Alberta as a special planning area". ${ }^{18}$ This is meant to implement provincial policy on land around airports, on the protection of major transportation or utility corridors, of green belts around them, and possibly of land for new towns. ${ }^{99}$ The Act, however, specifies no such purposes and thus the power is limited only by the overall purposes of the Act.

Remarkably broad regulation-making powers are provided to the Lieutenant Governor in Council in respect to a Special Planning Area. Under section 144(2) he may prohibit or regulate and control the use, development or occupation of land or buildings; the exercise of any power indicated in the regulations by a specified Minister of the Crown or a government agency; the demolition, removal, (re)construction of buildings or other things. He may regulate and control the height, location or size of buildings. As well, he can authorize purchase or expropriation of any interest in the land; prohibit any expropriation under the Expropriation Act ${ }^{50}$ and he may confer on any Minister any power or duty under the regulations (this latter provision should be interpreted as identifying the specific powers which may be granted, not as creating new ones). The regulations, unless specified therein, override any plan or land use by-law under the Act. ${ }^{51}$

45. S. 143.

46. S. 143(4).

47. Padfield v. Ministry of Agriculture et al. [1968] 2 W.L.R. 924 (H.L.).

48. S. 144(1).

49. Speech of Honourable Dick Johnston, Minister of Municipal Affairs, supra n. 8.

50. S.A. 1974, c. 27.

51. S. 144(4). 
Presumably, the existing Restricted Development Areas which have been created under section 15 of the Department of the Environment Act ${ }^{52}$ will eventually be proclaimed under the Planning Act and the powers of the Minister of the Environment in this regard will be repealed.

\section{Can Development Control Continue?}

Now that the major provisions of the new Act have been described, the new land use by-law can be examined. It is contended that under the new Act, municipalities can either continue as they have in the past, or be innovative if they wish. Indeed, the English form of development control could virtually be duplicated, as it could have been under the old Act.

1. Development Control Under the Old Act

At this point, it may be helpful to outline the development approval process under the former Planning Act. Basically, municipalities could choose between conventional zoning (with permitted or conditional uses)or development control, provided the Minister approved their application for a development control order. Under the development control approval system each development application is assessed on its individual merits, case by case, based on sound planning considerations. In its best known English form, there are no zoning constraints laid down in advance. Instead, general criteria, usually laid down in a plan, would provide policy direction for the approval agency. In Alberta, the Development Officer was to "have regard to" the General Plan whether under preparation or adopted ${ }^{53}$ Of course, the Development Officer was also bound by the Development Control By-Law, some of the contents of which were laid down in the Act ${ }^{54}$ and in the Minister's Development Control Order. ${ }^{.5}$

The legislation also authorized, but did not require, a municipality using development control to pass a resolution making "rules respecting the use of land" (hereinafter "Rules") by which the Development Officer was to be governed. ${ }^{56}$ It should be noted that both the By-law and the Rules required approval by the Provincial Planning Board.$^{37}$ No mandatory contents for the Rules were specified in the Act. Provision was also made for a land use classification guide ("Guide") and a schedule of permitted land uses ("Schedule"), which might also be prepared, but which were not part of the Development Control By-Law. ${ }^{\mathbf{5 s}}$

\section{Calgary's Use of Development Control}

Let us see how the City of Calgary, the main Alberta city which used development control exclusively, implemented the scheme. Although no contents were specified by the former Act for the Rules, Guide or Schedule referred to above, Calgary proceeded as follows. The rather brief Development Control By-Law (By-Law 8600) (with numerous exceptions, including single family dwellings, and duplexes in lower density land use classification areas)

52. S.A. 1971 , c. 24 as am. 1972 , c. $91 ; 1974$, c. $27 ; 1975(2)$, c. $51 ;$ c. 65.

53. Old Act, s. 100(2).

54. Id., ss. 104(2) and 105.

55. Id., s. 103(b).

56. Id., s. 106(1).

57. Id., s. 111 - presumably the approval was to be by the Board - and s. 106(2).

58. Id., s. 107. 
forbad development without a permit, specified the material to be submitted with an application, and authorized the Development Officer, or in some cases the Municipal Planning Commission, to decide on applications. Approval could be with conditions "having regard to the general plan, design brief, or other policy guidelines ...".

Calgary's Rules Respecting the Use of Land, the contents of which were not laid down in the former Act, but which required approval by the Provincial Planning Board, ${ }^{50}$ contained detailed provisions equivalent to the specifications in a typical zoning by-law for setbacks, parking, minimum site and yard areas, height and bulk controls, and so forth. Separate provisions (including bonuses) were made for the downtown area. Minor variance power was given to the approving official. Because these detailed Rules bound the Development Officer, and because there usually was conformity with the Guide and the Maps, Calgary's system was only a weak version of the British development control.

The Land Use Classification Guide and Schedule of Permitted Land Uses divided the city into districts, with reference to Land Use Classification Maps, and specified the "permitted" uses for each district. Direct Control districts could be created, with uses approved by the Planning Commission "on the merits of each individual application having regard to" conformity with the plan, existing uses of neighbouring lands, or previous zoning or policy on annexed land. In other words, there was real development control within these districts.

Under the former Act the flexible nature of Calgary's approval process stemmed more from the appeal process than the original approval process. "An aggrieved person" ${ }^{80}$ could appeal a decision of the Development Officer to the Development Appeal Board, which was not bound by the Rules, Guide or Schedule. The D.A.B. was to

consider each appeal having due regard to the circumstances and merits of the case and to the purpose, scope and intent of a general plan ... and to the development control ... by-law ...."

Regardless of the meaning of "due regard," the D.A.B. had a considerable amount of discretion - so much so that many developers and some politicians had been pressing for a return to zoning. Of course, this discretion had to be exercised quasi-judicially ${ }^{62}$ but its decision was final, subject to appeal to the Appellate Division of the Supreme Court of Alberta on a question of law or jurisdiction. ${ }^{63}$

\section{The New Act}

The new Planning Act would permit Calgary to continue its bastardized version of development control, or even to adopt the real thing. The new land use by-law may resemble zoning, butit is so flexible that development control could easily be accommodated. The municipality must be divided into districts, but of the number council thinks appropriate. ${ }^{64}$ Arguably, that

59. Id., 8. 106(2).

60. Id., 8. $128(1)$, as am. S.A. 1973 , c. 43.

61. Id., $128(4)(c)$.

62. Actus Management Ltd. v. Council of City of Calgary [1975]6 W.W.R. 739, at 745 (per Clement J.A.).

63. Old Act, s. 146(1).

64. S. 67(2)(a). 
could be as few as one..$^{65}$ One or more uses of land or buildings must be prescribed ${ }^{68}$ but instead of absolutely permitting them, the by-law can attach conditions or make approval at the discretion of the Development Officer. ${ }^{67}$ Provisions for the usual site, height and bulk controls may be made. ${ }^{68}$ Furthermore, if a general Municipal Plan has been adopted direct control districts may be created. Within these districts council "may regulate and control the use or development of land or buildings ... in such manner as it considers necessary". ${ }^{69}$

It is submitted that even the English form of development control can be accommodated within these sections, probably within sections 67 and 69, but certainly under the direct control district permitted by section 68 . There are no apparent limitations on the number of these districts. ${ }^{70} \mathrm{~A}$ municipality might therefore create one direct control district over the whole of its territory. Even if a minimum of two districts is required, another "country residential" or agricultural district surrounding the developed area could easily be designated.

It is submitted, however, that a municipality could base its development control by-law on sections 67 and 69, and create various districts with extremely wide discretion in the Development Officer.

\section{E. Innovative Zoning Techniques}

\section{Conditional Zoning}

A wide range of innovative zoning provisions could also be employed under the new Act. Using discretionary uses, it would be easy to achieve the same effect as conditional zoning or its less reputable brother, contract zoning, Combining discretionary uses, direct control districts and council's power to require a development agreement as a condition of approval, a Planned Unit Development (P.U.D.) might be negotiated.

\section{Planned Unit Development}

\section{(a) The Development Agreement in Alberta}

The breadth of development agreements which are statutorily authorized is obviously germane to a consideration of various innovative negotiated zoning techniques. Therefore, before exploring the P.U.D. concept it would be useful to discuss the status of development agreements under the new Act. The new Act's mandate on development agreements in sections 75 and 89 seems narrower than the former Act's, and this could interfere with the range of items which could legally be negotiated with developers. Nevertheless, other authority for the agreements will be suggested below.

A discussion of the authority under the old Act is unnecessary for the purposes of this paper. In some significant ways, the new Act seems to narrow this authority, although some important ambiguities exist. The following is a summary of the apparent situation under the new Act.

65. Under 8. 18(1) of the Interpretation Act, R.S.A. 1970, c. 189, “... words in the plural include the singular...".

66. Ss. 67(2)(b) and $69(1)(a)$.

67. S. 67(2)(b) and (d)(vi).

68. S. 67(3).

69. S. 68 .

70. The use of the singular in $\mathrm{s.68}$ “ $\ldots$ and area ... designate that area ..." includes the plural. Interpretation Act, supra n. 65, s. 18(1)(i). 
Section 89(1) of the new Act permits a subdivision approving authority, at the request of a council, to require an applicant to enter into an agreement with council for the construction of certain roads and infrastructure at the developer's expense. Section 75 allows a council to require agreement on the same items at the development stage (the only difference between the provisions being the words "subdivision" and "development"). The former power at the subdivision stage to require "all necessary public roadways", etc. ${ }^{71}$ or "all or any . . . public roadways" etc. $^{72}$ to be built at the applicant's expense has been changed to the roadway "required to give access to the development." At the permit stage, the former Act's authority for the requirement of "the installation of utilities and other necessary services" under development control ${ }^{73}$ and for "the supply to the building of water, electric power, sewage ..." under zoning ${ }^{74}$ has been changed to "installation of utilities ... necessary to serve the development...". ${ }^{75}$

Various interpretive problems arise. For example, there is the question whether a developer has provided "access to the development" by building a road from an already existing major roadway to the development entrance, without building any interior roads. It is also unclear whether "utilities ... necessary to serve the development" must serve each parcel. Surely they must, and it is to be hoped that the courts will interpret these powers regarding development agreements broadly. ${ }^{76}$

Subject to these ambiguities, however, development agreements are clearly authorized with reference to infrastructure. Under section 67(3), councils may also provide for "the amount of land ... around or between buildings" (clause 3); "the landscaping of land or buildings" (clause 4); "the design, character and appearance of buildings" (clause 7) and "the density of population in any district or part thereof" (clause 15). The question is whether these may be required as terms in a development agreement. Since a limited number of subjects for such an agreement is authorized in section 75 , the ordinary implication is that no others can be required. ${ }^{17}$ Clause 17 of section 67(3), however, authorizes a land use by-law to provide for "the establishment of such agreements, forms, fees and procedural matters as the Council considers necessary". Although the other items in this list are of a more modest scale and the ejusdem generis rule could be invoked, the "agreements" authorized must have some scope and could strongly be argued to include agreements between the city and private developers at least in respect of the matters itemized in the same subsection.

71. Old Act, s. 16(e).

72. Former Subdivision and Transfer Regulations, Alta. Reg. 215/67 s. 17(1), as am. 292/75.

73. S. 104(3).

74. Id., s. 124(4).

75. Ss. 75(b) and 89(b).

76. Another less pressing interpretive quandary arises from the power to require the construction of or payment for "off-street or other parking areas", which the development agreement may require. Other than "off-street" must mean "on-street". Do we therefore conclude that the cost of any percentage of street area on which parking will be allowed can be levied against a developer?

77. A developer cannot be required to enter into a development agreement without statutory authority (Rogers, Canadian Law of Planning and Zoning (1973) 101, as am. Release no. 6, August, 1978). 
The new Act also requires a land use by-law to provide for the conditions and restrictions that may be attached to a development permit, and for the discretion the Development Officer can exercise. ${ }^{78}$ No specific authority is given there for development agreements to be entered into on these points, but clause 17 of section 67(3) again may be sufficient here.

Finally, section 68 should be noted. A council which has adopted a general municipal plan may designate a direct control district if it desires to exercise particular control over development. In such a district, council may "regulate and control the use of development of land or buildings ... in such manner as it considers necessary". Such a broad mandate should cover the use of development agreements. (Again the power in section 67(3) might suffice.)

\section{(b) The Planned Unit Development (P.U.D.) Concept}

P.U.D.s can be briefly discussed. Generally, these are intended to maximize flexibility in design, arrangement and mix of development within a large scale project. They were originally developed through the efforts of Desmond Muirhead, when designing housing communities in connection with his famous golf courses. He persuaded approval authorities to lay down broad performance standards, and then to assess the adequacy of his specific design solution. Instead of using conventional detached single family homes on a lot basis, he achieved the appropriate densities and street setbacks with townhouses and clusters of units.

Although the concept was originally developed for housing projects, it was later extended into industrial and commercial developments. ${ }^{7}$ Muirhead and others successfully argued the "self-administering", standard zoning and site planning controls are too rigid and detailed because of their need to establish standards in advance of development. This form of land use control in a dynamic community is utterly inappropriate. ${ }^{80}$

The P.U.D. was an attempt to inject flexibility into this standard zoning process, especially in the American context where development by development adminstrative control was distrusted by the courts. ${ }^{81}$

That it succeeded shows that the "development control versus zoning" debate is arid, as both can be used to achieve the necessary flexibility.

The equivalent of P.U.D.s could have been achieved under the former Act more than they were. Under the new Act, apart from the financial aspects of the provision of infrastructure,$^{82}$ municipal authority for P.U.D.s appears to rest on sections $67(3)$ or 68 .

\section{Interim or Holding Zones}

Although formidable political objections may arise to holding or "interim" zoning, especially if downzoning without compensation is involved (authorized primarily by former section 135 and the present section 4), it

78. S. 67(2)(d)(iv) and (vi).

79. Kransnowiecki, Legal Aspects of Planned Unit Development in Theory and Practice, in Listoken (ed.), Land Use Controls: Present Problems and Future Reform (1974) 185.

80. See, inter alia, Heyman, "Innovative Land Regulation and Comprehensive Planning" (1972) 13 Santa Clara Lawyer 183 at 186-7.

81. Kransnowiecki, supra n. 79, at 186.

82. Ss. 75 and 89 (b). 
seems to have been allowed by both the old and the new Acts. Certainly the new Act's direct control section is tailor-made for this purpose. ${ }^{83}$

\section{Bonuses}

Bonussing systems are widespread in various development approval systems. They involve making formula concessions such as a higher floorarea ratio to a developer who "voluntarily" provides an amenity - be it arcades, plazas or, in Calgary, a "plus-15" walkway system - which is not required by the by-law or rules. The Calgary Rules Respecting the Use of Land (which bound the Development Officer) specifically authorized bonuses for downtown development and for some residential development. There is no doubt that this system can continue whether under true development control which would entail site-specific negotiations between the development officer and the developer, under Calgary's version of development control, or under a mechanically applied bonussing formula under conventional zoning.

\section{Air Rights}

It is also noteworthy that the former Calgary Rules provided for bonuses within an approval process for "air rights development" over public right of ways. These were authorized under section 175.1 of the Municipal Government Act ${ }^{84}$ by which a council can lease air space over public roadways. The massive "Canada Square" development over the C.P.R. tracks in downtown Calgary, which involved negotiations with the railway and the federal Ministry of Transport, began a trend which can continue under the new Act.

\section{Transfer of Development Rights (T.D.R.)}

The Transfer of Development Rights (T.D.R.) could also be used to preserve historically or architecturally significant buildings from redevelopment.

T.D.R. involves the compensated transfer of development rights from one site, which government for a variety of reasons does not wish to see developed, to another to allow a higher density development on the latter site than would otherwise be allowed. Difficult technical problems must be overcome, but the technique has been successfully used in New York City, to preserve meritorious buildings, and a number of American states or municipalities are enacting the necessary statutes or ordinances. ${ }^{85}$ Although adequate payment for the lost opportunity cost or the preserved site can maintain the economic viability of the less intensive use, the transfer must not overbonus the new site and hence impose an undesirably heavy impact on its environs.

It is popular to suggest that because true development control involves no development "rights" to transfer, T.D.R. could not be used under the Alber$\tan$ systems of development control. But this overlooks the obvious analogue to the Calgary bonus system just discussed, which, by the way, also allows the transfer of the bonuses at the discretion of the Planning Commission. ${ }^{\mathbf{8 6}}$ T.D.R. can be viewed as a form of bonus, and can be employed under development control to the same extent as can bonussing.

83. S. 68 .

84. R.S.A. 1970 , c. 246 , as am. S.A. 1971, c. 74 , s. 19, and S.A. 1975(2), c. 17, s. 22.

85. See Helb, Charoushian and Nieswand, Development Rights Bibliography (1976).

86. Resolution of the Council of the City of Calgary adopting Rules Respecting the Use of Land 29 May 1972, Appendix 18, Downtown Development Standards, clause 7. 


\section{Floating Zones}

This technique involves a description of permitted uses and more or less detailed regulations on the design and form of those developments, but without specifying where the zone would be located. The decision as to location would be made after assessing various proposals for a development of the relevant sort, multi-family housing, a shopping centre or whatever.

The same result was achieved under the former zoning which preceded development control in Calgary, and approval of the project survived a court challenge ${ }^{87}$ Under conventional "spot" zoning which is well accepted in Canada, the same result could be achieved, although somewhat less openly.

The new Act does not seem to permit floating zones as such. Districts created under the land use by-law, including direct control districts, have to be designated. Of course, the creation of "discretionary uses" in any zone is permitted ${ }^{88}$ and would allow a particular type of development to "float." As well, a re-zoning is always possible.

\section{IS THE NEW ACT BETTER OR WORSE?}

\section{A. A General Assessment of the New Act}

Drafting a Planning Act, and planning, are highly complex because of the extraordinary number of social, economic, environmental and value variables. It is therefore always easy to criticize a plan for being incomplete, while other critics may decry its obsolescence due to the inordinate preparation time.

It is for this reason that some commentators ${ }^{89}$ argue that the process and procedures of plan preparation are more important than the finished product. Rather than concentrate on an end state blue print, it is argued, planners must concentrate on specifying methods for the evaluation of public policy choices, which is the central task of the planning process. Thus, instead of concentrating on a plan with physical design and land use maps, (which are often ignored in the development approval process unless land use by-laws enshrine them), planners should enunciate broad policy goals, performance standards and criteria.

As well, it is claimed, they must develop procedures to ensure these statements are considered, together with the public's value choices and private rights, in the evaluation of development proposals. Indeed, the basic problems in planning, far from being quantitative, concern aesthetics, values and social philosophy.

In evaluating a planning statute, one should consider both what it requires and what it allows. In what follows, the identified shortcomings are usually failures to require or encourage innovation or improvements in the planning and approval process rather than positive obstacles to their achievement. As well, there are drafting ambiguities and omissions to complicate the picture.

The purpose of the Act has been broadened to include "beneficial" as well as "orderly" and "economical" development, "use" as well as "development",

87. Cohen v. Calgary (City) and Carma Developers (1967), 60 W.W.R. 720 (Alta. S.C. App. Div.).

88. Ss. $672(b)$ and $68(2)$.

89. See Roberts, The Reform of Planning Law (1976). 
of "patterns of human settlement" as well as "land". ${ }^{90}$ This does reflect a welcome increase in perspective, particularly with the new goal to

maintain and improve the quality of the physical environment within which patterns of human settle. ment are situated in Alberta ... ${ }^{\circ 1}$.

The Act's specific provisions for the realization of these objects will be considered later, but it should be noted that the purpose section in the former Act was used by the courts to aid in interpreting the statute..$^{92}$

The new Act exempts from its provisions any development or subdivision effected solely for public roadways, oil and gas wells or batteries, pipelines or anything else specified by regulation. ${ }^{93}$ Although this list of exemptions is somewhat shorter than the former Act's, ${ }^{94}$ these exemptions are still formidable. Regional and municipal planning for "orderly and economical" development can obviously be completely nullified by decisions as to the routes or location of the specified things. The reservation of these decisions to the province may be justifiable, since other regulatory bodies, such as the Energy Resources Conservation Board, will no doubt advert to land use planning considerations, and environmental issues are often referred to the Minister of the Environment. ${ }^{95}$ However, the relationship of planning permission and the approval process for resource development and other environmentally significant projects is of great importance. It does not seem to have been sufficiently addressed, and until it is, much more consultation than in the past must precede these decisions, and the blanket power to exempt other things from the Act must be used extremely sparingly.

The lack of specification of plan contents will be discussed below, but the new power of a Regional Plan to "regulate and control the use and development of land" R.P.C. chose to prepare a detailed plan with maps. Under both the former and new Acts, the Regional Plan is binding on municipalities within the region. ${ }^{97}$

Although the new Act provides for plan amendment procedures, ${ }^{98}$ no provision now requires that plans be updated, on a five year or any basis, although the former Act required it for all plans. ${ }^{\theta \theta}$ This omission is curious, even if it does increase local autonomy.

90. S. 2(a).

91. S. 2(b).

92. Usually the reference has been of a general nature, as in City Abattoir (Calgary) Ltd. v. Council of City of Calgary (1969), 70 W.W.R. 460, per Smith C.J.A.; Actus Management Ltd. v. Council of City of Calgary [1975] 6 W.W.R. 739, per Clement J.A. at 743; and Dallinga v. Council of City of Calgary [1976] 1 W.W.R. 319, per Prowse J.A. at 324. But in Re Giannone's Appeal (1961) 35 W.W.R. 320 Milvain J. referred to the purpose section as "the most important provision" of the Act (at 327). He then decided that since some commercial development (a shopping centre and service station) had been approved, refusing the requested hotel part of the complex would infringe on the rights of the land owner more than was necessary in the public interest for orderly development. He therefore approved the whole development.

93. S. 3 .

94. Old Act, s. 18(1).

95. See Coal Conservation Act, S.A. 1973, c. 65, ss. 21 and 24; The Hydro and Electric Energy Act, S.A. 1971, c. 49, s. 10; and The Oil and Gas Conservation Amendment Act, S.A. 1972, c. 74, s8. 7(b) and $9(\mathrm{~b})$.

96. S. 46(b).

97. Old Act, s. 79, New Act, s. 53.

98. Ss. 54-8, 135-138.

99. Old Act, ss. 83 and 97. 
One potentially troublesome provision of the new Act allows the use of reserve land (including environmental reserve) ${ }^{100}$ for building and maintaining a public roadway or public utility, "if the interests of the public will not be adversely affected". ${ }^{101}$ Under repealed section 128(5) of the Municipal Government Act ${ }^{102}$ only public parks could be used in this way. The courts at least have been given a statutory test to apply, although they are very diffident about interfering with an elected body's determination of public interest. At least the new Act forbids alienation of environmental reserve. ${ }^{103}$

The relation of plans and land use by-laws is unsatisfactory. Although all statutory plans and land use by-laws must conform to the Regional Plan, ${ }^{104}$ the Act fails to specify that a land use by-law must conform to the General Municipal Plan or to Area Plans. If a Regional Plan were couched in terms of general policies and criteria, it is easy to imagine a land use by-law which could conform to them, and yet be in breach of land use districts specified in a General Plan which might itself conform to the Regional Plan. This is remarkable and unfortunate. If plans need not be binding on a land use bylaw, why not forget them and merely relate the by-law to the Regional Plan? In the same vein, a Development Officer is bound to issue permits for nondiscretionary uses permitted by the land use by-law, ${ }^{105}$ but is nowhere bound by the plans. Presumably this reflects conscious choice, but since both the plan and the by-law require the same formalities to pass or amend, it is hard to see the rationale. Certainly community associations will be horrified to learn not only that the Area Redevelopment Plan (which they were told had been given statutory recognition) does not bind the land use by-law, but that the reverse is true. Of course, this problem can be met by simultaneous enactment of a plan and consistent land use by-laws.

Let us now proceed to examine the statute from the points of view of centralism versus local autonomy, public participation and environmental considerations.

\section{B. Is the New Act Too Centralist?}

Whether the new Act centralizes too much is a complex question. It involves deciding the appropriate role of planning and the desirable areas of control by local and central governments. In turn, these issues raise questions of the function of social, economic and environmental factors, whether municipal planning should be mandatory or optional, what the legal status of a plan should be, the extent to which its contents should be specified, and whether provincial approval of plans should be required. In short, resolving the conflict between the legitimate principles of central control and local autonomy involves a notion of the ideal municipal plan, and the ideal planning and implementation processes.

Space is lacking to do justice to these questions, but before assessing the new Act's adequacy, it might be helpful to make some tentative remarks about them.

100. S. 1(37).

101. S. 114 .

102. Supra n. 84.

103. S. 115.

104. S. 53(2).

105. S. $69(2)$. 
In a time of concern about big unresponsive governments and public participation, maximum local autonomy, consistent with overall strategic direction by the province, should be a guiding principle. Where decisions have largely local implications, local citizens and government should be in the best position to make the choices for their living environments. If the choice is wrong, the remedy is for those affected to take the necessary political action to change the municipal council (and I say that as a conspicuously unsuccessful candidate in the 1977 municipal elections in Calgary). ${ }^{106}$

The obvious difficulty is that many apparently local decisions have broader implications. For example, a growing city which chooses a low density form may expand into valuable agricultural land, and this urban form also makes viable public transportation impossible. The resultant waste of resources is of provincial and national concern. Therefore, a provincial government should create some constraints on local planning and approval decisions, either by requiring that these sorts of impacts be addressed, or by preventing wasteful patterns from being perpetuated.

What is the proper function of planning? Of course, all levels of government should plan each sector of their activity, and ensure overall coordination thereof. Both at the departmental and governmental levels, objectives must be agreed upon, alternative implementation strategies and policies weighed, courses of action (programs) selected and implemented, with continuing assessment of their effectiveness. The "proper role" of planners in whatever department is to ensure that this process occurs. Therefore, although most planning legislation appears to do so, it is foolish to see planning as something uniquely physical, or land use oriented - social planners, policy analysts, organization and management specialists, financial and budgetary officers are equally planners. But this factalso warns against the imperialistic tendencies of many planners in municipal planning departments to see all possible planning activity as within their primary responsibility. ${ }^{107}$ If it were so, they would form the only municipal department which generated policy for ratification by council. Admittedly, this stance is partly a reaction from the unfortunate ability of transportation and engineering departments with tunnel vision to make important physical growth decisions, regardless of the planning department or the municipal plan. Surely the realistic function of the municipal plan is to provide overall policy for land use decisions. Public sector decisions would include locations and construction of public transit, roads and other infrastructure, public buildings, cultural and recreational facilities. In respect of private use of land, the plan would lay down a set of principles on overall growth, density and use patterns.

106. Space does not permit discussion of the serious municipal finance problem, but consistent with the principle of maximum local autonomy, provincial funding should generally be unconditional. In 1974, provincial grants (virtually all conditional) amounted to $66 \%$ of education, $74.8 \%$ of health and $62.3 \%$ of social service expenditures by municipalities (Plunkett and Betts, The Management of Canadian Urban Governments (1978), 74). K.G. Crawford wrote that the increased supervision and control implied by this trend threatened a "progressive weakening of local self-government to the point that it might better be abandoned and replaced by a system of local government agencies" (Canadian Municipal Government (1954), 359).

107. Part of the problem, it seems, is the organizational structure of various municipal departments which carry out planning roles. Careful thought is needed to ensure the coordination of these activities and consequent policy decisions. 
Overall, the plan should specifically discuss the desired growth sequence, its form, and its financial, social, environmental and resource use implications. It would not, however, seek to be the source for all social, health and welfare or financial policies. Only where land use decisions have implications for these activities, or vice versa, should the ramifications be discussed in the plan. For example, a municipal plan might state an overall social goal of equal access to municipal facilities, which could imply decentralization and construction of neighbourhood facilities for public libraries, clinics, and other social services. The same goal would also imply a comprehensive public transportation system so that the poor or elderly could get to museums, parks, community halls, or athletic facilities. Similarly, the financial and taxation implications of different urban forms and transportation systems should be discussed in the plan, although the municipal budget and consequent setting of the mill rate would remain in the conventional fiscal and budgetary process.

Naturally, plans for overall social services and for schools, police or fire service should also be prepared, but if aspects thereof did not affect land use, they would not be analysed in the municipal plan. Ensuring the coordination and consistency of the various plans is the responsibility of council and senior municipal officials.

Thus, the plan is not meant as a structure for overall municipal management, but as a prime source of policy on land use decisions by whatever municipal department, not just through the land use approval process for private applications. Where current road or sewer construction proposals conflict with the plan, the conflict should be explicitly and carefully dealt with by council, whether or not the plan is legally binding. If the plan is to be contradicted, it should be amended by the required procedures.

The previous discussion suggests that the preparation of a suitable municipal plan would require background studies at least of the community's social, economic, demographic, transportation, environmental, recreational and cultural characteristics.

The questions now to be addressed are whether the preparation of a plan should be mandatory, and if so, what provincial requirements should be created in terms of mandatory policies or contents. Further, what legal status should the plan have?

If planning is so fundamental to good government, one might expect that it would be done whether or not required by statute. But many jurisdictions in Alberta and elsewhere have had land use control by-laws for many years without any plans to speak of. So this point is not self evident.

Plans should not be prepared frivolously. They should provide policy guidance or a decision making framework for the management of change. Since virtually all communities are changing, statutory requirement of plan preparation makes sense. The requirements should, however, allow municipalities the flexibility to plan for their type of situation, not to prepare an encyclopedic plan for every imaginable contingency.

On the other hand, just requiring "planning" is not sufficient.

After twenty-five years of their use it cannot be said that a thoroughly satisfactory official plan has been produced in any municipality in Ontario. ${ }^{108}$

108. Ontario Economic Council,Subject to Approval A Review of Municipal Planning in Ontario (1973), 58. 
Therefore, it would seem, to ensure the highest quality of plan possible, clear statutory guidance should be provided.

Simultaneous provision for guidance and flexibility may be difficult, butit can be done. For example, the statute could require a relatively sophisticated list of background studies to be prepared or topics to be included in a regional plan. Regional planning commissions should have the resources to carry out such a mandate, whereas smaller municipalities would not. Further, such new requirements as environmental base line inventories or criteria for preserving natural areas seem more appropriate at the regional scale. For regional and municipal plans alike, the statute could require certain procedures for adequate public participation and impact analysis, both of which will be discussed later.

Rather than forcing the municipal plan to cover the gamut of topics from infrastructure and transportation, economic development and social services to land use patterns, it might suffice to require policy statements on only those features which are undergoing significant change, with statements of their direct or indirect implications affecting land use. Of course, municipal plans and implementation by-laws should have to comply automatically with the applicable regional plan.

The orientation of these suggestions is that a municipality should not have to automatically prepare a taxonomic municipal plan covering all contingencies. Instead, the municipality, before passing by-laws on topics in such a taxonomy, should have to address explicitly their planning and policy implications, including their relationship to regional plans. In turn, policies in these planning documents should legally constrain the contents of the implementation by-laws. Thus, only "relevant planning" should be required of a municipality. If the reply is made that it is impossible to deal with metropolitan areas, small towns and rural municipalities in the same sections of the Act, they could be dealt with separately.

Because of the principle of maximum local autonomy, municipal plans should not require provincial approval so long as aggrieved citizens can challenge in court the failure of the plan to comply with either statutory directives or the regional plan. Since regional plans are more strategic and far reaching documents, it may be appropriate to require provincial approval to ensure compliance with statutory requirements and other provincial policy. This policy, wherever possible, should be enshrined in regulations or orders.

Provincial governments should have a broad overall economic and social strategy for the prosperity and flourishing of their citizens. Where regional and municipal planning affected these provincial goals, the Planning Act should ensure strategic consistency. This principle goes beyond the requirement of relevant studies, procedures and topics for plans, and suggests some specific policy directions by a province for all regions and municipalities.

The Government of Alberta has often failed to articulate its overall policies. Such vital activities as the petroleum and coal industries and accompanying environmental control have been the subject of lengthy public debate and explicit policy formation, but for guidance in many other areas (especially in overall goals), one often must resort to ministerial speeches delivered several years before, perhaps by a previous minister of the relevant provincial department. In some cases, policy seems not even to be written down, much less contained in legally binding form, nor to be consistently understood inside or outside the government. 
This is true in land use planning. For example, although some sources indicate that agriculture and tourism must be long run pillars of the provincial economy, there is no statutory indication that land which is especially suited for these activities should be preserved from urban development. ${ }^{100}$

It is true that the new Planning Act allows (rather than requires) the provision of "environmental reserve," suitability for development, than because of its greater suitability for some other form of use, or the need to preserve it for environmental reasons. Surely statutory leadership on these issues would have been appropriate. The Act might have required impact studies of major developments be carried out to determine the comparative benefits of the proposed and other uses, in socioeconomic as well as environmental terms.

It is almost true, and to be applauded, that the new Subdivision Regulation requires a subdivision approving authority in a rural municipality to refuse subdivision for "country residential use" unless the subject land has a low agricultural capability. ${ }^{11}$ The Regulation also limits the dimension and location of subdivision for uses in the vicinity of highways. ${ }^{122}$ However, various overall requirements including, for example, the preservation of valuable agricultural land, unique natural environments, pure water supplies, and floodplain land from inappropriate development would have been useful additions to the Act. There will be more comment on these environmental matters later.

The new Act takes an important step by requiring all municipalities over a certain population to prepare a general municipal plan $^{113}$ and land use bylaw. ${ }^{114}$ Although the former Act specified a minimum list of surveys and studies as the basis for a plan, and also certain minimum contents for the plan, ${ }^{116}$ the new Act requires no background studies and the specified contents are at the level of "the present and future land use and development"116 and "the land use proposed" and "the manner of, and sequence proposed for, future development." ${ }^{117}$ (Interestingly, the optional Area Structure Plan and Area Redevelopment Plan do specify required contents in much more detail). ${ }^{118}$

The omission of mandatory background studies removes former requirements for, inter alia, surveys and studies of such important topics as public and social services, to say nothing of other standard studies needed for physical planning. Another former salutary requirement which has been omitted is for five year proposals for financing and programming public development projects and capital works. ${ }^{119}$ Surely such requirements would

109. See, however, discussion accompanying footnotes 111-12.

110. Ss. 92(b) and 95 .

111. Alta. Reg. 132/78, s. 21(1).

112. Id., ss. 23 and 25 .

113. S. $59 \cdot 1,000$ or more for all but counties or municipal districts, where the minimum population is 10,000 .

114. All municipalities with a population of 1000 or more $-\mathrm{s}$. 66(1).

115. Old Act, ss. 69 and 95.

116. S. 46 (for a Regional Plan).

117. S. 61 (for a General Municipal Plan).

118. Ss. 62(2) and 65.

119. Old Act, s. 95(c) (v) as am. S.A. 1973, c. 43. 
not have trespassed unduly on municipal autonomy or on their resources. In an era of tight budgets, especially for social services, these omissions may come back to haunt us even if an aroused municipal citizenry (also in short supply on planning issues) could set the matter right at the polls.

Another criticism could belevelled against this and other acts which affect urban problems. In many ways, our society is at the crossroads. Both our environmental and resource use habits must become much more sensitive and parsimonious. Innovative techniques are needed to use our resources more wisely. Yet while the possibilities are there for imaginative municipalities, the province has failed to exert leadership.

Take public transportation. Cars carrying only their drivers are a terribly profligate way for workers to commute to downtown jobs. The provincial government professes to favour public transportation improvements, but has been reluctant to increase funds for Light Rail Transit systems to which Calgary and Edmonton are committed. ${ }^{1199}$ Furthermore, the province has not tried very hard to persuade these cities that simultaneous massive road developments and further low density urban form will simply prevent these expensive fixed route rail transit systems from being viable. Indeed, the province has recently allowed Calgary to annex an additional 25 square miles of land for low density housing, which in terms of servicing and land costs will not only add several thousands of dollars for servicing and land to the cost of each unit, but will continue to militate against effective public transit.

In significant ways, then, it could be claimed that insufficient central direction is being provided by the province. (It could also be claimed the higher provincial grants for roads perversely distort local transportation planning against public transit). The Planning Act's critics, however, who claimed it was too centralist were referring to more conventional planning and land use approval issues. The validity of such criticisms may now be assessed.

A number of changes of detail have been made, some of which add to Regional Planning Commission or municipal powers, some of which subtract from them, and some of which could do either. ${ }^{120}$ The importance of some of these changes is in the eye of the beholder, but the most significant increase in regional or local autonomy (some of which have already been argued to be inappropriate) seem to be relaxed requirements about the contents of

119 a. During the recent provincial election campaign, the province announced major transportation grants without specifying whether they had to be used for roads or public transit.

120. See ss. 26(3) (a Regional Planning Commission can no longer have duties imposed on it by Regulation); 29(1) (instead of one half of the members of a Municipal Planning Commission having to be appointed officials, council now has freedom of appointment, a change opposed by a submission of the City of Calgary's Planning and Law Departments April 11, 1977); 32(1) (instead of Calgary and Edmoton being by statute the only municipalities with subdivision approving powers, the Minister may now delegate these powers to the Council of other municipalities with a plan and land use by-law); 33 and 34(1) (a Development Appeal Board now must be created, but Council has freedom of choice in whom to appoint); 59 (the perparation of a Municipal Plan is now obligatory, although there is no lonnger a requirement that it be updated every 5 years); 66 (Council must pass a land use by-law); 67(4) (Council can now set the time which must elapse before an application similar to one rejected can be made for the same land (s. 124(2) of the old Act said six months)); and 113 (the disposal of reserve land surplus to municipal requirements no longer has to be approved by the Provincial Planning Board). 
municipal plans, ${ }^{121}$ the possibility that more municipalities will become subdivision approving authorities, ${ }^{122}$ greater freedom of appointment to Municipal Planning Commissions and Development Appeal Boards, ${ }^{123}$ and the fact that municipal plans and land use by-laws no longer have to be submitted to the Provincial Planning Board, either for its information or approval. ${ }^{124}$

As indicated earlier, ${ }^{125}$ municipalities retain great flexibility of land use control techniques. This, and the fact that permission is no longer needed to implement a form of development control, indicates greater local autonomy.

The most important shifts toward central control appear to be the new requirements that municipalities adopt a plan and land use by-law ${ }^{126}$ and the new power by regulation to direct a council "to amend its land use by-law to include any prohibition or regulation and control of development."122 Potentially, this latter power could result in continual meddling by the province in local planning matters. The former corresponding section ${ }^{128}$ permitted the Minister to order a Council to conform, enforce, or to enact plans or by-laws, but conferred no power to specify contents. It is to be hoped that this broad new power will be used judiciously.

Subject to the last point, it does not appear that the new Act is too centralist. Indeed, as has been argued, it could have provided more central leadership.

Another criticism of the new Act has been that it lengthens the approval process. ${ }^{129}$ Space does not permit an examination of the merits of this claim. Although the evidence is equivocal, it is submitted that municipalities which seriously wish to eliminate delays and complexities have it largely within their power to do so. Some streamlining has been achieved although, in respect of replot procedures, sections 120 and 127 require two public hearings where none was required before.

\section{Public Participation}

Because the municipal level of government is the closest to the people, and its decisions can have such direct impact on local social and physical environments, the need for structured citizen input into these decisions is especially acute. At the same time, the mechanics of local participation can be somewhat simpler and more direct than at the provincial or federal levels.

121. Ss. 44,46 and 61 .

122. Ss. 32(1) and $85(a)$.

123. Ss. 29(1) and 34(1).

124. Old Act, ss. 100, 106, 107, 111, 112, 130(7).

125. See supra, text accompanying footnotes $64-70$, and subheading "Innovative Zoning Techniques."

126. Ss. $59(1)$ and 66.

127. S. 142(1)(d).

128. Old Act, s. 142.

129. The Subdivision Regulation creates a lengthy list of local authorities and persons who, depending on the location of the land, are to be sent copies of a subdivision application (Alta. Reg. 132/78). Each of these recipients has a legitimate interest, but money and time could be saved if minor subdivisions were exempted from at least parts of this complex circulation, or if municipalities who can approve subdivisions were authorized to make the decision on behalf of some of these bodies. 
The earlier enthusiasm of decision makers for public participation has waned, and many interest groups have become cynical about its usefulness. As much as possible, the reason for this loss of commitment must be dealt with in designing realistic public participation.

From the point of view of governmental decision makers or project proponents, there appear to be several more or less valid reasons for disillusionment. They have perceived that so-called "community" or "public interest" groups have often been negative and confrontation oriented in their behavior. Further, these groups have seemed to them to be irrational and even narrowly self-interested in their opposition to many projects. They also have seemed uninformed. Finally, they have reacted to adverse decisions, even when they have been fully heard, by claiming that they were not given a genuine chance to influence the decision. It has seemed to government and industry that many of these groups did not want input, but at leasta veto and possibly full decision making power.

Without attributing blame or bad faith, these perceptions have often been caused by structural reasons - which could have been changed by government or industry action. If community groups are presented with fully designed projects, supported both by industry and government, what can the groups do but organize confrontation and protest against aspects which they do not like? If the necessary information is not released in time for careful analysis, what can the group do but react with "back of the envelope" analysis? What is wrong with creative use of the news media by protest groups, when both industry and government shamelessly use them for propaganda purposes?

Even the patently selfish community opposition to all social housing, rehabilitation homes or multiple family development is understandable when the project proponents have not consulted the community in any meaningful way.

Community groups, on the other hand, cite examples of token participation and deception in some consultative procedures. Most believe that the decision makers have already made up their minds before the public hearings or other input procedures. It is extremely frustrating to have legitimate discussions of underlying values or the broad implications of a project shunted aside as "irrelevant," or to have reasoned briefs which technically demolish a proponent's case branded as "opposition to progress" or too narrow in perspective. Often it must seem that drama, nonviolent protest and even civil disobedience are justified in the face of such treatment.

The remedy to many of these perceptions lies in some simple principles. First, elected representatives have the right and the duty to make basic policy choices. ${ }^{130}$ Second, formal, legitimized avenues should exist for full and early involvement in planning and decision making, prior to, as well as during, implementation. If too many individuals or groups wish to become involved (this in itself is a valuable indication of the perceived importance of the decision to be taken), umbrella or coalition groups might have to form to keep numbers manageable. Third, the relevant information must be published in plenty of time for opinion to form and for proper analysis. Fourth,

130. This is not the occasion to speculate about whether representative democracy should or could give way to a more direct and accountable form of participatory democratic government. 
government should not assess, or give approval in principle to, a project until these steps have been followed, although city planners, for example, might usefully be involved in these preparatory steps. Fifth, some sort of public forum should be available when approvals are being considered. Sixth, the validity of an argument should rest primarily on its intellectual force, rather than on the implied threat of political harm if a project is approved or refused. This is perhaps an overly naive statement, since political reality is always in the background, and since the strength of neighbourhood feeling can be relevant. Nevertheless, decision makers have to try genuinely to keep an overall perspective of the public interest. A lone voice may express the truth, and a well organized political protest group or developer's lobby can be wrong.

It is important to realize that the deck is stacked in favour of project proponents, because of the disparity of resources. Some financial and technical support should be available for community groups. This will tend to improve the quality of the debate which should be, after all, the best guarantee of better decisions.

It might be feared that mechanism for these procedures would add appreciably to the length and expense of the development process. ${ }^{131}$ But the extent to which they are used will probably correspond to the importance of the decision involved, and it is unproductive if community groups have to spend most of their scarce volunteer resources just to blast their way onto the agenda. The quality of their arguments should be their main focus.

The process implied by these remarks, although not a panacea, should in many cases result in plan adjustments, or agreement early enough that lengthy hearings will be minimized. Better projects can also result, to say nothing of the public and individual benefits of participation in complex decisions which affect people's lives.

It is important to remark that involvement opportunities in the preparation and approval of regional, municipal and area plans, while necessary, are not sufficient, even when combined with an appeal mechanism in development approvals. Major transportation and public construction projects must be included, as well as significant individual redevelopment or housing initiatives. Public involvement mechanisms must be integrated into the impact analyses suggested in the next section.

Let us now assess the public involvement contemplated by the new Act. At the regional level, the Regional Planning Commission must "encourage, by whatever means it consider appropriate, participation by the general public in planning matters". ${ }^{32}$

As well, the R.P.C. must provide an opportunity, during the preparation of a regional plan, for the Provincial Planning Board, local authorities and "persons affected" to make suggestions. ${ }^{133}$ These provisions leave room for creative experimentation, and the Act goes on to specify some minimum procedure. Two stages are contemplated, an invitation to make suggestions before or after the preparation of a draft (with a copy of the draft to go to

131. Obviously these detailed, formal procedures are not required for a building of a garage or house even if an appeal process is desirable for this level of development decision.

132. S. $26(3)(d)$.

133. S. 47(1). 
councils in the region and person or organizations considered necessary by the R.P.C. $)^{134}$ and a public hearing at which anyone wishing to be heard, who has complied with specified hearing procedures, can appear. ${ }^{135}$ The R.P.C. must "consider the representations".

It might have been better to require provisions for citizen involvement in the preparation of a draft plan, although the number of municipalities in. volved and the size of regions militate against this. Nevertheless, each municipality could have been required to set up an advisory committee to help its R.P.C. representative if a demand therefore were made in a specified way. Rather than being unduly demanding at the regional level, however, let us pass on to the municipal level.

Again, an opportunity must be provided during the preparation of a General Municipal Plan for persons affected to make suggestions. ${ }^{137}$ Remarkably, no such requirement exists at the level most suited for it - the area level - except that before second reading of any by-law adopting any statutory plan or land use by-law, a public hearing must be held. ${ }^{138} \mathrm{~A}$ new provision requires that each owner of land which is the subject of a proposed amendment to a land use by-law be given written notice and a summary thereof. ${ }^{139}$ The procedure to be followed is similar to that just described for adoption of a Regional Plan, with the same obligation to "consider the representations". ${ }^{140}$ Apparently, if a council applies, the Minister may exempt it from any or all of these requirements, ${ }^{141}$ even when material amendments are involved, since non-material amendments are specifically exempted by a different section. ${ }^{142}$

Provisions also exist for access to other information than the proposed plan and supporting material. Reports submitted to the Provincial Planning Board, Regional or Municipal Planning Commissions, and minutes of their meetings may be inspected and copied, although copies can be ridiculously expensive. ${ }^{143}$ At the Development Appeal Board level, the public may inspect before (it does not say how long before) the public hearing "all relevant documents and materials respecting the appeal". ${ }^{114}$

Section 149 of the Municipal Government Act ${ }^{145}$ allows any elector to inspect any contract approved by council or an executive committee, any report of the commissioners, any committee or official once it has been submitted to the council (except for legal opinions or reports), and minutes adopted by the council. The obvious difficulty with these provisions is that often these documents go to council only three or four days before a decision.

134. S. 47(2) and (3).

135. S. 48 .

136. S. 49 .

137. S. 60 .

138. S. 135 .

139. S. $135(2)$.

140. S. $136(2)$.

141. S. 137.

142. S. 138.

143. S. $42(1)$. The rate which can be charged is up to 50 cents per 100 words or $\$ 1$ per page.

144. S. 82(4).

145. R.S.A. 1970, c. 246, as am. S.A. 1971, c. 74, s. 12. 
An egregious and insulting example occurred during a lengthy public participation program carried on as part of the City's review of the Calgary General Plan. After numerous public meetings to discuss various growth alternatives that the Planning Department had identified, the Commissioners submitted their new "balanced growth strategy" to Council on a Friday for approval the following Monday. Council supinely accepted this procedure and of course endorsed this alternative which no member of the public had seen before.

The Municipal Government Act should be amended to provide that documents on which council is expected to act should, except in carefully specified circumstances, be available in the public domain for a reasonable period of time. Of course, a possible reply is that this is a matter for individual councils to decide.

Applying the principles listed above, it is easy to see serious deficiencies in these procedures. Apart from an opportunity of making suggestions during a General Municipal Plan's preparation, there is no participatory planning contemplated, not even for community associations during the preparation of neighbourhood plans, let alone significant development projects. Any bylaw involving major expenditures for such projects as a road network or Light Rail Transit, can be passed without any public participation whatever, so long as neither the land use by-law nor plan needs amendment.

One relatively simple reform would be to require, as part of an application for a development permit for significant developements, a description of the consultation with and information made available to, the relevant community association, and the seeking of the latter's comments on the proposed project. This would formalize a procedure which sometimes already occurs on an ad hoc basis, and would encourage more meaningful and earlier citizen involvement.

Affected community associations or even interested individuals should have a statutory right to participate in the preparation of area plans. Some technical or financial assistance should be available in this process, which would include participation in the preparation of impact statements discussed in the next section.

Some of these changes involve legal recognition of the existence of community associations, but that was recommended in the "Red Book" ${ }^{146}$ It is suggested that the rather simple changes suggested herein can be implemented without undue delay or expense. It must be acknowledged, however, that a municipality which desires to implement them has the option of doing so under the new Act.

\section{Environmental Concerns in the New Act}

Some general remarks should be made about the role of environmental factors within the land use planning and approval processes. Because of space limitations, however, these will not be detailed or elaborated. The framework presented here leans heavily on an excellent study by Reg Lang and Audrey Armour, ${ }^{147}$ and follows themes presented earlier in this article.

146. Alberta Municipal Affairs, Towards a New Planning Act for Alberta (1973). This was the original report released to the public for comment.

147. Lang and Armour, Municipal Planning and the Natural Environment, Background Paper 3, The Planning Act Review Committee (Comay Committee), Ontario Ministry of Housing (1977). 
It should first be noted that there is no attempt here to define environment to include all economic and social as well as physical systems, or to imply that all identifiable results of an initiative are "environmental" impacts. Just as we earlier limited a general plan's scope to aspects of social and other services or programs with land use implications (or vice versa), so we resist overloading the term "environment." Environmental factors should be integrated into all relevant planning, whether within the general plan and land use approval process or within other departments. The concept of "impact assessment" would be equally applicable to the process of analysing financial or social implications of a development. Thus, if we agree that these implications should be considered, that various kinds of assessments must be coordinated and integrated where possible, and that ultimately the conclusions of these studies must be weighed holistically, we can escape the dilemma of determining whether some implication is "environmental". We can thus free our analysis to include, where relevant, such topics as energy and resource use, financial and social implications of a proposal, as well as more traditional environmental considerations like pollution, aesthetics, conservation of unique ecological features, and safety of residents and property.

Environmental concerns must, of course, be considered not only in the various land use plans, but just as importantly, in the approval process. The questions which need to be answered during the approval process are often too precise and site specific for direct application of general environmental principles expressed in a plan. It will be a matter of studying the "actual effects of specific actions on specific environments". ${ }^{148}$ Even so, the prediction may be extremely difficult and small scale approvals with post construction monitoring may be a safer and more sensitive way to proceed than trying to give long term and large scale direction in a plan.

The importance of urban development has led one American study to conclude that

decisions affecting the use, development, maintenance and redevelopment of land, is (sic) perhaps the most important determinant of environmental quality, particularly the quality of the urban environment where the vast majority of our citizens live. ${ }^{100}$

The same conclusion seems applicable to Canada. We must also recall that environments are not merely threatened by huge resource development projects, but

are equally degraded by numerous, incremental and seemingly minor changes which accompany land use and "development", in turn generated by urban industrialization, concentrated population growth and a high-consumption lifestyle. ${ }^{\text {so }}$

The challenge is to provide a planning and approval process which will preserve environmentally important land from development, prevent overly-intense or inappropriate development of ecologically vulnerable areas, and weigh the secondary and cumulative environmental effects of development. This is extremely difficult, for one housing subdivision may be satisfactorily designed for its natural setting, and its runoff might be tolerable. But without a rigorous legal framework, it may be difficult to prevent subsequent adjacent subdivisions, equally well designed, but

148. Id., at p. 47 .

149. Kaiser et al. Promoting Environmental Quality Through Urban Planning and Controls U.S. Environment Protection Agency (1974), at 31.

150. Lang and Armour, supra n. 147, at 2. 
whose cumulative runoff might seriously damage a creek or river. In turn, an engineering solution such as flow regulation might destroy valuable ecological features of the stream.

It seems clear, from experience elsewhere, that merely implicit statutory authority to include a satisfactory environmental component in a plan is woefully inadequate. In a study of about one third of Ontario's Official Plans, Lang and Armour found that the three most frequently included environmental concerns were safeguarding residents and property from environmental hazards such as flooding or slumping (48\%), minimized pollution $(46 \%)$ and aesthetics $(43 \%)$. The protection of agricultural land appeared in $11 \%$ of the sample, and conserving resources such as timber and minerals in $5 \%{ }^{151}$ Energy was not mentioned at all, and "only $2 \%$. . . stated that all other goals in the Plan should attempt to satisfy the environmental goals". ${ }^{152}$ Overall, their survey

showed that the planner's concept of the environmental characteristics of "land" tends to be weak (it is still seen largely as a commodity), and that the linkages between environmental quality and human activities receives (sic) minimal attention. ${ }^{183}$

Lang and Armour identified barriers to addressing the natural environment in the Ontario municipal planning process, including a lack of adequate concepts and information, concern for feasibility and legal defensibility, and the reluctance of councils to place any more restrictions on land development, because of political pressure and the financial costs of buying sterilized land. ${ }^{154}$ Nevertheless, they pointed to examples of draft plans, both regional (Waterloo) and municipal (Oakville). The former contained explicit policies to protect environmentally sensitive areas, using three classes of environmental protection area. Within these areas, no develoment was to be allowed which would have a major impact on the relevant natural feature, and environmental impact analysis was to be the tool for making this decision. ${ }^{135}$ The Oakville draft contemplated "an Environmental Plan and Environmental Review Process as a component of the Official Plan and part of the Plan Review". ${ }^{156}$

Naturally, environmental planning can include more than environmental protection zones and impact analysis, although if additional principles are provided to guide the development approval authority they are of course major steps forward. Even if these counter examples of environmental planning do exist, provincial direction is needed to ensure sound environmental planning (the importance of which is assumed herein). Because of the lack of resources and knowledge in many municipalities, specific statutory provisions and provincial policy and procedure manuals are necessary if timely progress is to be made in this field.

Lang and Armour concluded that

First, Official Plans are weak in content, narrowly interpreting natural environment as safety of residents and property, pollution control and aesthetics. Second, development controls are weak, both in the attention they give and the degree of protection they afford to the natural environment; the

151. Id., at 8.

152. Id., at 15 .

153. Id., at 14 .

154. Id., at $12,13,19$ and 20.

155. Id., at 51-2.

156. Id., at 51. 
most popular controls, in floodplains, exhibit serious deficiencies with respect to data and jurisdiction. Finally, the linkage between plans and implementing measures; usually missing is the necessary linkage between an environmentally -oriented planning goal (such as preserving a unique habitat) and the means to achieve it. ${ }^{157}$

Before looking at the new Alberta Planning Act, several brief points should be made. First, since municipal boundaries rarely respect natural features or ecosystem boundaries, strong ecological planning is essential at the regional level. Of course the regions may themselves contain only part of a natural system, and this fact alone requires provincial intervention to coordinate the necessary ecological planning.

Second, there are reasons to doubt that long term plans are sufficiently sensitive to be the main instrument for environmental planning. True, environmental protection areas can be identified and preserved (if the necessary environmental baseline date are obtained), and a kind of sensitivity index can be produced through the use of overlays, computer mapping or whatever. The problem, rather, is to assess the specific results of a specific proposal for a specific site. This indicates careful impact assessment during the approval process.

Let us return to the specific statutory guidance which is needed. All levels of plan need environmental principles which would be appropriately established by legislation. A partial list of suggested principles would include items already covered, and would provide either incentives or prohibitions to ensure more efficient utilization of land and resources. This would involve dramatic shifts in priority to public transportation, more dense forms of housing development, and might involve performance standards on energy consumption, and environmental impact. The impact not only of a development on its environs but on urban systems should be measured. For example, low density housing might not strain the immediate environment too much (although it costs much more to service and consumes more land), but it would militate against the success of efficient public transportation, which needs a certain density to be viable. The implications of this may be the wasteful duplication of a road network and exclusive right of way public transit, and the devastation of inner city communities by more roads for suburban commuters to downtown. It seem that such a blunder has been made in Calgary, which has simultaneously committed itself to Light Rail Transit and annexation for more low density development. The folly of the latter may doom the potentially valuable former, and it could delay adjustment to an energy and resource short future by many years.

Two other points. It is not enough to state various desirable goals, and then consistently sacrifice the environment when conflict becomes obvious. The conflict should be addressed both in the plan and land use by-law. Preserving an area for forestry is not the same as preserving it as a natural area. While careful practices can leave a highly desirable wildlife habitat, clear cutting is often a menace. Water management often cannot achieve sewage or industrial effluent disposal and recreational goals at once, and pretending they can is a de facto sacrifice of the recreation potential. Intensive chemical agriculture can seriously conflict with environmental goals. It can pollute soil and water, threaten species and seriously interfere with recreation and even human health. So merely zoning land for agricultural use may not achieve environmental protection without careful management. 
The last point is that plan preparation, impact assessment and land use approval processes must be open so that legitimate interests can participate publicly in the decision.

As already mentioned, the purpose section of the new Act refers to the adoption of measures to "maintain and improve the quality of the physicial environment". ${ }^{168}$ Although Giannone's Appeal ${ }^{159}$ showed that the section will be specifically applied by the courts, there is a difference between the urgency with which Albertans view the protection of individual rights, which was the point there, and the improvement of the environment. The real test of the Act's adequacy rests in its implementation sections. Here, it does not measure up.

The Act's lack of direction on provincial policies or on plan contents has already been criticized. ${ }^{160}$ Let us examine implementation of environmental policies at the regional level, including direct (and often ad hoc) intervention by the Minister of the Environment, and then provisions for municipal decisions.

The regional level is often the most appropriate for the designation of environmental protection areas. No environmental mandate whatever is specifically given to the R.P.C., but section 15 of the Department of the Environment Act ${ }^{161}$ gives significant powers to the Lieutenant Governor in Council to create Restricted Development Areas or Water Conservation Areas. The Minister of the Environment must first report that the establishment of the area is needed in the public interest for various purposes, including prevention of pollution of natural resources (defined by section 1 to mean "land, plant life, animal life, water and air"), protecting watersheds, retaining the environment in a natural state, preventing environmental deterioration because of incompatible uses, or confining to land within the Area operations which might adversely affect any natural resources, or cause any pollution.

Sections 15(2) and 17 of that Act give broad regulation making powers to the Lieutenant Governor in Council. Where he establishes a Restricted Development or Water Conservation Area, inter alia, he may provide for control or restriction of any use or occupation of land, for the control or restriction of the exercise of any governmental power specified, for purchase or expropriation of land, or for "any other matter or thing necessary or incidental to the protection or improvement of the environment of the Area". 162

Under section 17, general regulation making powers include "requiring persons owning ... . land to refrain from using that land in any matter detrimental to the environment ..." ${ }^{163}$ Numerous regulations have been promulgated under these powers ${ }^{164}$ often requiring the consent of the Minister of the Environment before certain activities are approved, and occasionally

158. S. 2(b).

159. (1961) 35 W.W.R. 320 (Alta. S.C.).

160. See supra, subheading "Is the New Act Too Centralist?".

161. S.A. 1971, c. 24 , as am.S.A. 1972, c. 91 , s. 42; 1974, c. 27 , s. 70(4); 1976, c. 65, s. 3(3); and S.A. 1977, c. 61, c. 3.

162. Id., s. 15(2).

163. Id., s. 17(b).

164. See Alta. Regs. 285, 286, $287 / 74$ as am. 212/76, 9/78. 
forbidding the exercise of any power under a whole list of acts (nine in the case of Edmonton's "Capital City Recreation Park Restricted Development Area"). ${ }^{168}$ Draconian fines are provided for breaches of the regulations, often a minimum of $\$ 1,000$ for a first offence. ${ }^{186}$

Obviously these powers have great importance for environmental and other aspects of planning, although it may be argued that detailed administration should not be by provincial authorities. The preamble of the Calgary R.D.A. Regulations ${ }^{167}$ refers to the need to "coordinate and regulate the development and use" of the relevant lands, and to the need to control "the continuing deterioration of the quality of the environment... resulting from the further uncoordinated growth of the City ...". This particular area almost surrounded the City (except for an Indian Reserve), and was partly intended to reserve land for a road and utility corridor - truly, planning at the regional scale (although unhappily, through circumventing the regional planning process). A similar motive for establishing the Area around Edmonton was struck down as being ultra vires ${ }^{188}$ the Lieutenant Governor in Council, but section 15 was amended with retroactive effect ${ }^{169}$ and the new section appears to give the necessary authority.

The motivation behind these areas is laudable, even if more consultation would have been desirable. Some of the boundaries, however, appear to have been drawn more with an eye to their symmetry or political appeal than with reference to their ecological characteristics. Nevertheless, the remarks about the lack of provincial direction in planning should be read with these counterexamples in mind. Overall, these powers would permit, and have permitted, strong provincial leadership over certain environmental aspects of land use planning.

The R.P.C. is given power by section 46 of the new Act to provide for, and to regulate and control, the use and development of land in the region. This could be interpreted as conferring power to create natural zones of various sorts. Although the Act specifically denies any right of a person to compensation for planning and zoning decisions, the problem of sterilization of private land is taken care of indirectly. General municipal plans and land use by-laws must conform to the regional plan ${ }^{170}$ and when land is designated, inter alia, for parks, in order to conform with the regional plan, it must be bought by the relevant council, unless the Crown or other local authority does so, within a short period of time. ${ }^{171}$ Thus the problem is solved for land which can be characterized as park, although the position is.not clear for any environmental protection area which could not be so designated.

Somewhat the same position exists for plans at the municipal level.

At the subdivision stage, the Act forbids approval unless the land is suitable for the intended purpose ${ }^{172}$ and although provision is made for re-

165. Alta. Reg. $9 / 78$, s. 7.

166. See Alta Regs 285/74, 286/74, 212/76, 9/78, s. 11.

167. See Alta Regs. 285, 286, $287 / 74$ as am. 212/76, 9778 .

168. Re Heppner and the Minister of the Environment for Alberta (1978), 80 D.L.R. (3d) 112 (Alta. S.C. App. Div.).

169. S.A. 1977, c. 61.

170. S. 53(2).

171. S. 70.

172. $S .88(1)(a)$. 
quiring environmental reserve, it is descretionary. ${ }^{173}$ The list of land forms which may be required as environmental reserve is marginally broader than before ${ }^{174}$ but there is no mention of preserving escarpments, ecologically significant or aesthetically desirable areas. The overwhelming motives are to prevent hazardous lands from being developed, and to prevent water pollution - hardly the sort of environmental planning advocated above.

At the development stage, the Act is not satisfactory. The possibility exists that the land use by-law could create districts consisting entirely of discretionary uses, and it could explicitly require the weighing of environmental factors by the Development Officer. But the Act does not require any such factors to be considered.

Section 67(3) authorizes provision to be made about the "design, character and appearance of buildings", so aesthetics are specifically recognized. As well, the development of buildings on land subject to flooding, or which is marshy or unstable, or within a specified distance of a body of water permits more than mere building hazards to be considered. Headwaters and marshlands could be protected for ecological reasons if a council wished to do so.

For the most part, however, environmental factors are not taken into account by the Act or the Regulation, ${ }^{175}$ and it is up to individual municipalities to adopt the concern and include it into their by-laws. There do not seem to be serious obstacles if a municipality decides to engage in ecological planning or impact analysis, although such techniques as scenic easements are not currently authorized, nor is there any provincial provision for such new concerns as the right to unobstructed sunlight for solar heating. ${ }^{178}$

Mention should be made briefly of other provincial legislation relevant to environmental quality, although we must confine ourselves to provisions relevant to the regional or municipal focus of this article.

The Municipal Government Act ${ }^{177}$ contains numerous sections concerning public safety, sanitation and health, recreation and community services and

173. S. 95 .

174. Coulees, land subject to flooding, or unstable land have been added to the list, and the former category of "land ... unsuitable for building sites or private use" (Old Act s. 25(3)) is now "land ... unsuitable in its natural state for development" (s. 95(c)). As well, the former mandatory requirement of a strip of land along bodies of water (former s. 25(4)) has been widened from not less than ten feet to not less than twenty feet, but made discretionary (s. 95(d)). Of course, it could be argued, in the context of a minimum having been stipulated, that this provision is mandatory, but this is the only subsection with such a minimum, and term "may require" applies to them all.

175. As mentioned previously, the Subdivision Regulation forbids subdivision in a rural municipality for country residential use unless the land involved has a low capability for agricultural use (which is not further defined) (Alta. Reg. 132/78, s. 21(1)). As well, the Regulation limits highway commercial and other development, apparently from similar motives (ss. 23-4). Further, it specifies lot sizes which are of course bigger for areas not intended to be served by sewage systems (ss. 14-19). Provisions are also made regarding the proximity of residential subdivisions to such potential nuisances (or hazards) as landfill sites, sewage treatment plants or lagoons, livestock feeding lots (s. 12) and sour gas facilities (8. 13).

Under the Regulation, subdivision approving authorities must consider, inter alia, topography, soil characteristics, storm water collection and disposal (s. 8). There is no reference to ecological value, need for preservation of water supply (for example, in headwaters) and the orientation is exclusively suitability for development, as opposed to its possibly greater value for other long term purposes. These provisions, far from showing comprehensive environmental awareness, are only a modest beginning.

176. See Ontario Ministry of Energy, Perspectives on Access to Sunlight (1978).

177. R.S.A. 1970, c. 246 as am. 
public works and public utilities. Recent provisions have been added to this Act to allow the establishment of malls ${ }^{178}$ and lease of air space over roadways. ${ }^{179}$

The construction and operation of a wide variety of industrial plants, structures, or things specified by the Director of Standards and Approvals or by regulation must be approved by permits or licenses under the Clean Air and Clean Water Acts ${ }^{180}$ and regulations. Naturally all terms and conditions in these approvals must be observed.

Section 8 of the Land Surface Conservation and Reclamation Act ${ }^{181}$ gives the Minister of the Environment the power (but not the duty) to order an environmental impact assessment where anyone proposes an activity likely to result in surface disturbance. Interestingly, the Act applies to "all lands within Alberta," including those within municipal boundaries, unless specifically exempted. The only significant exception is "subdivided land used or intended to be used for residential purposes." ${ }^{182}$

Under this Act, lakeshore land development has been designated a "regulated surface operation" under the Land Surface Conservation and Reclamation Act. ${ }^{183}$ One of the kinds of development controlled is " ... the preparation of unsubdivided lands to be used for the purpose of industrial sites or for recreational or residential development". ${ }^{184}$ Applications must be approved by the provincial Land Conservation and Reclamation Council. No approvals for lakeshore development of this and other kinds specified may be given unless there exists a Land Use By-law, giving effect to a Lake Management Plan, and with which the proposed development conforms.

In summary, although there is insufficient direction regarding environmental matters by the new Planning Act, other sources of authority at least permit vigorous provincial intervention.

\section{CONCLUSION}

It was claimed earlier that various innovative zoning techniques, or indeed development control, will be possible under the new Act. Many provisions in the new Act can be criticized from the point of view of both policy and draftting, and the Act may be judged especially deficient for failing to give sufficient leadership, rather than for being overly-centralist. Subject to one important area, the provisions of reserves, the approval process under the new Act will not have to be longer than under the former Act. The Act is inadequate on environmental and public participation grounds, although other provincial legislation provides some protection for the environment.

Given the time and effort available, and considering the complexity of the subject matter, the Act is reasonably good. Nevertheless, significant amendments can be proposed.

The Act has been assessed by taking for granted the legitimacy and importance both of planning and (usually) of contemporary societal and attitudinal

178. S.A. 1971, c. 74, s. 18 and $1975(2)$, c. 17, c. 22.

179. Id., 1971, c. 74, s. 19, 1975(2), c. 17, s. 22.

180. S.A. 1971 , c. 16 as am.

181. S.A. 1973, c. 34.

182. Id., s. 2(2)(a).

183. Alta. Reg. 233/77.

184. Id., s. 1(g). 
constraints. At a deeper level, of course, it is easy to dismiss many of the concerns of the Act, and of my technical criticisms, as fiddling while Rome burns. Although attitudes are slowly changing, there is as yet little awareness in Alberta (or in North America for that matter), that we are living not just in an age of change but one of crisis. The human race faces starvation through drought, desertification, and climatological change, much of which is brought on by human action. Our descendants face the risk of misery and suffering from a shortage of resources, and environmental degradation and pollution - all from human action.

In the face of such overwhelming problems, it is easy to understand people's feelings of impotence or even the pretence that life can go on as usual. On the contrary, many of these problems arise from a fundamental crisis in which we are complicit - the crisis of unjust distribution of resources and power. Profound matters of justice, rights and responsibilities arise, and it is not enough to adopt the competitive "sauve qui peut" attitude to the weak or incompetent. Instead, we must work in cooperative ways and perhaps insist less on "retaining my property" and more on "helping my neighbour".

Why does this have to do with the Planning Act, or Alberta? Simply because all the problems listed above have to be solved on specific pieces of land by specific people, and Alberta has many resources relevant to these solutions. We have good agricultural land which must be saved to feed people. We have a "fuel's paradise" of hydrocarbons, and we are morally responsible for how these and other Albertan resources are used. Some day human suffering may result from our wasteful squandering. Our cities, and our regions, must be planned so as to husband resources for the future. Our progress should be measured by our stewardship, not our consumption.

These are merely examples of the many ways that planning can be relevant to encourage equal access to opportunities, and convivial societies. Naturally conviviality and fairness are fundamentally related - each is necessary for the other, and planning affects both.

At the same time, we must acknowledge that the Planning Act of Alberta, or even all provincial actions, cannot make much of a dent in these large scale problems. But the least we can ask is that nothing be done which can exacerbate the situation. And under the Planning Act, municipalities can still choose policies which will do so. As a society, we not only fail to ask the overwhelming questions, we do not even seem aware of their existence. 